\title{
Entrepreneurial ecosystem and sustainability as catalysts for regional development: proposition of a theoretical framework
}

\author{
Ecossistema empreendedor e sustentabilidade como catalisadores do \\ desenvolvimento regional: proposição de um framework teórico
Ecosistema emprendedor y sustentabilidad como catalizadores del desarrollo regional: propuesta de un modelo teórico

\author{
Paulo Vitor Siffert ${ }^{1}$ \\ Liliane de Oliveira Guimarães ${ }^{1}$
}

Received on 07/22/2019; reviewed and approved on 12/11/2019; accepted on 01/13/2020 DOI: http://dx.doi.org/10.20435/inter.v21i4.2647

\begin{abstract}
The demands for a development model that considers the social and environmental dimensions, as well as the economic dimension, has become increasingly imperative, either by society in general or by the initiative of national or supranational bodies, as oversight and regulatory agencies. In this way, the precepts of sustainable development have been gaining more space in political agendas and civil debates. We propose here that this model of development, especially the one linked to strong sustainability (and relative to the branch of ecological economy), would be ideal. For this, based on literature review, we formulate a theoretical model that combines sustainable regional development (as a dependent variable), mediated by the independent variables of entrepreneurship and sustainability. That is, the objective of this paper is the proposition of a theoretical framework that assumes that the sustainable regional development can be reached from the articulation between the foment to the entrepreneurial activity and the precepts of sustainability. As an additive to this model, we also consider the construct of the entrepreneurial ecosystem as a catalyst for entrepreneurial activity at the regional level and sustainable entrepreneurship as a type of business conducive to a more equal income generation, improvement of social structure, and environmental preservation.
\end{abstract}

Keywords: Sustainable development; entrepreneurship; entrepreneurial ecosystem; sustainable entrepreneurship; sustainability.

Resumo: As demandas por um modelo de desenvolvimento que contemple as dimensões social e ambiental, além da econômica, vêm se tornando cada vez mais um imperativo, seja por parte da sociedade em geral, seja por iniciativa de órgãos, nacionais ou supranacionais, fiscalizadores e reguladores. Dessa forma, os preceitos do desenvolvimento sustentável vêm ganhando cada vez mais espaço nas agendas políticas e nos debates civis. Propomos aqui que esse modelo de desenvolvimento, em especial aquele ligado à sustentabilidade forte (e relativo à economia ecológica), seria o ideal. Para isso, baseados em revisão da literatura, formulamos um modelo teórico que conjuga desenvolvimento regional sustentável (como variável dependente), mediado pelas variáveis independentes empreendedorismo e sustentabilidade. Ou seja, o objetivo deste artigo é a proposição de um framework teórico que assume que o desenvolvimento regional sustentável pode ser atingido a partir da articulação entre o fomento à atividade empreendedora e os preceitos da sustentabilidade. Consideramos também, como aditivos a esse modelo, o constructo ecossistema empreendedor como catalisador da atividade empreendedora em nível regional e também o empreendedorismo sustentável como um tipo de negócio propício para a geração mais igualitária de renda, melhoria na estrutura social e preservação ambiental.

Keywords: Desenvolvimento sustentável; empreendedorismo; ecossistema empreendedor; empreendedorismo sustentável; sustentabilidade.

Resumen: Las demandas por un modelo de desarrollo que contemple las dimensiones social y ambiental, además de la económica, se están volviendo cada vez más un imperativo, sea por parte de la sociedad en general, sea por iniciativa de órganos, nacionales o supranacionales, fiscalizadores y reguladores. De esta forma, los preceptos del desarrollo sostenible vienen ganando cada vez más espacio en las agendas políticas y en los debates civiles. Proponemos aquí que este modelo de desarrollo, en particular el vinculado a la sostenibilidad fuerte (y relativo a la economía ecológica), sería el ideal. Para ello, basados en la revisión de la literatura, formulamos un modelo teórico que conjuga el desarrollo regional sostenible

\footnotetext{
${ }^{1}$ Pontifical Catholic University of Minas Gerais (PUC Minas), Belo Horizonte, Minas Gerais, Brazil.
} 
(como variable dependiente), mediado por las variables independientes del espíritu empresarial y la sostenibilidad. Es decir, el objetivo de este artículo es la proposición de un marco teórico que asume que el desarrollo regional sostenible puede ser alcanzado a partir de la articulación entre el fomento a la actividad emprendedora y los preceptos de la sostenibilidad. Consideramos también, como aditivos a ese modelo, el constructo ecosistema emprendedor como catalizador de la actividad emprendedora a nivel regional y también el espíritu empresarial sustentable como un tipo de negocio propicio para la generación más igualitaria de renta, mejora en la estructura social y preservación ambiental. Palabras clave: Desarrollo sostenible; emprendedorismo; ecosistema emprendedor; emprendimiento sostenible; sostenibilidad.

\section{INTRODUCTION}

A number of studies show that entrepreneurship plays a key role in the development of a region (AUDRETSCH, 2003; KURATKO; MORRIS; SCHINDEHUTTE, 2015; MÜLLER, 2016), both for their potential to create new employment and raise per capita income, as well as for the dissemination of an entrepreneurial culture (SZERB; ÁCS; KOMLÓSI; ORTEGA-ARGILÉS, 2015). Thus, the spatial concentration of a relatively high number of entrepreneurs, development and research institutions (public or private) would enable higher rates of entrepreneurship and regional development (MORRIS; NEUMEYER; KURATKO, 2015). In this context, the creation of a new type of local productive arrangement - democratic, by encouraging all types of new companies, not only technology-based firms seeking aggressive growth; and dynamic, as it is a system permanently open to new entrants - has been gaining greater prominence among practitioners and researchers: the entrepreneurial ecosystem (STAM, 2015; MALECKI, 2018).

However, one-dimensional models of development - i.e. those that only contemplate the economic aspect - have been increasingly outdated and touted inefficient, and their "serious limitations" (BRUNDTLAND, 2012, p. 9) should be considered. The exclusion of the social and environmental dimensions from development indicators was a relatively untreated subject until the 1960s, when growing environmental problems and social injustices became increasingly flagrant around the world (LU, 1996; BANDARAGE, 2013). Since the 1970s, the debate on the concept of 'sustainable development' has grown. The term was formally coined in 1972 on the first United Nations Conference on the Human Environment held in Stockholm (BOLIS; MORIOKA; SZNELWAR, 2014). This terminology drew attention to the need to consider social and environmental issues when talking about development (HOPWOOD; MELLOR; O'BRIEN, 2005).

Since then, the term has been widely debated and appropriated by different social groups: Bolis, Morioka and Sznelwar (2014) point out that this concept dissemination has allowed the propagation of different, and often divergent, definitions of what was sustainable development. Among them, two are highlighted: the strong and weak approaches to sustainability (LU, 1996).

Acknowledging the bigger transformative potential of the strong sustainable development (HOPWOOD; MELLOR; O'BRIEN, 2005; BANDARAGE, 2013), we consider here strong sustainable entrepreneurship (STÅL; BONNEDAHL, 2016) as being the preferred to be encouraged within an entrepreneurial ecosystem (MORRIS; NEUMAYER; KURATKO, 2015, MALECKI, 2018). Sustainable entrepreneurship would effectively serve as a lever for regional development by locally promoting the dissemination of a comprehensive entrepreneurial culture (SZERB et al., 2015), with potential to transform the socioeconomic structure of a region while preserving its natural resources.

Hence, the objective of this paper is to propose a theoretical framework that contemplates a model of regional development that is, at the same time, sustainable and vigorous, as it 
promotes the restructuring of its socioeconomic context via a more democratic insertion of its local population in the productive cycle through entrepreneurship. Supplementary concepts are also considered: entrepreneurial ecosystem, based on its capacity to fulfil the potential of entrepreneurship for regional development; and sustainable entrepreneurship as a preferable approach to new firms creation as it is aligned with the assumptions of sustainable development.

In addition to this introduction, the paper is structured as it follows: chapter 2, where the literature review is presented; chapter 3 , in which the proposition of the theoretical model is presented; its discussion composes chapter 4 . At last, chapter 5 is composed of considerations regarding the contributions of the theoretical model for future research.

\section{LITERATURE REVIEW}

\subsection{Sustainable Development}

The models of development that have dominated the mainstream of the economic thought since the twentieth century are those derived from classical and neoclassical theories (BOLIS; MORIOKA; SZNELWAR, 2014). They handle, mostly, with issues related exclusively to economic growth (LU, 1996; BRUNDTLAND, 2012; BOLIS; MORIOKA; SZNELWAR, 2014). According to this approach, the increase of productivity - and the subsequent growth of the economy - would be the key element in achieving the wellbeing of humankind (HOPWOOD; MELLOR; O'BRIEN, 2005). Therefore, it is necessary to elucidate that we consider development as a multidimensional concept, which involves more than just economic criteria to validate it.

The lack of consideration for the environment in the mainstream development models has led to ecological problems that have accumulated over the decades and have gradually gained repercussions since the 1960s (LU, 1996; BANDARAGE, 2013). In other words, those widely diffused development models have been, since the twentieth century, segregating economic and environmental issues without showing interest in recognising the necessity to integrate both dimensions (LU, 1996; BRUNDTLAND, 2012).

Hopwood, Mellor and O'Brien (2005) indicate that the concept of sustainable development derives from the awareness of the existence of global links between growing environmental problems and socioeconomic issues related to poverty and inequality, generating concerns about a healthy future for humanity. The articulation of these three dimensions (economic, social and environmental) in a development model characterizes the fundamental tripod that structures the concept of sustainable development (BANDARAGE, 2013). Thus, the foundational argument for sustainable development is that economic growth at the expense of "uncontrolled depletion of natural resources is, by definition, not sustainable" (LU, 1996, p. 3).

Since the 1980s, theoretical discussions about sustainable development have advanced, triggering the emergence of different lines of thought that addressed the interrelationships between the elements that make up the basic tripod of sustainable development (HOPWOOD; MELLOR; O'BRIEN, 2005; BOLIS; MORIOKA; SZNELWAR, 2014). These different approaches are based, for example, on a polarized relationship between an anthropocentric or biocentric conception of sustainable development (LU, 1996); or by a relationship that combines beliefs in the ways in which environmental problems can be mitigated or solved (more technocentric or ecocentric solutions) with an active interest in reducing or maintaining social inequalities (HOPWOOD; MELLOR; O’BRIEN, 2005). 
A model proposed by Lu (1996) categorizes four approaches to sustainable development, in a spectrum that goes from a more anthropocentric to a more biocentric view. The anthropocentric position sustains that humankind is in a superior position in relation to nature and therefore has the right to subjugate it. This type of idea has contributed to a scientific-rationalist conception of the world in which the human and natural spheres are separated (LU, 1996) and that served as a basis for the developmental formulations praised by the classical and neoclassical schools of economics (STÅL; BONNEDAHL, 2016).

The biocentric view began to reverberate mainly in the 1970s, questioning the primacy of anthropocentric conceptions of the world and arguing that humans and nature should be perceived in a more integrated manner; along these lines, the idea of superiority and the right to subjugate nature would eventually represent future threats to the preservation of the human species itself. This view, although not dominant, gained enough strength - especially in the 1980s and 1990s - and began to "dilute" dominant anthropocentric conceptions, increasingly inserting environmental concerns in the mainstream development models (LU, 1996).

Hence, the model proposed by Lu (1996) would be comparable to a four-step ladder, where at the top would be what the author called the "ecological approach" - within the spectrum, the ideal biocentric conception of the world. At the bottom step of this ladder, there would be the "treadmill approach", where environmental issues would be completely overlooked in the debates about development and economic growth - a purely anthropocentric approach. In the middle of these two extremes, closer to the biocentric view, on the third step of this metaphorical ladder, would be the approach of "strong sustainable development"; in the second step and closer to the anthropocentric conceptions, would be the "weak sustainable development". These approaches would not be mutually exclusive, but rather represent a spectrum of schools of thought that can overlap in one or more aspects.

Because they present no environmental concern and virtually no commitment to reduce socioeconomic inequality, we could consider that those actors identified with the "treadmill approach" would find themselves outside the debate on sustainable development (HOPWOOD; MELLOR; O'BRIEN, 2005). On the other hand, Lu (1996) considers the "ecological approach" utopian, which would also alienate it from much of the debate. Thus, in this paper, our focus will be the strong and weak sustainable development approaches.

The ones associated with the strong sustainable development approach argue that economic development is not a precondition for environmental protection, but rather the opposite: environmental preservation would be an inexorable condition for economic development (LU, 1996). According to this approach, economic and public policies should focus on ways of guaranteeing the maintenance of the productive capacity of certain unique-value environmental assets that are priority in the preservation order (e.g. tropical forests) or that can be improved or recovered (e.g. degraded soils). The achievement of these objectives would involve market regulation and, to some extent, state intervention; on the other hand, it would call for the involvement and participation of local communities in order to develop local economies that make sustainable use of the surrounding environment (LU, 1996; BANDARAGE, 2013).

The strong concept of sustainable development also recognizes that there are certain natural resources that are unique, finite, and unlikely to be reproduced by humankind ingenuity and technological development: the ozone layer, photosynthesis and the water cycle are examples (HOPWOOD; MELLOR; O’BRIEN, 2005). This position derives from the school of ecological 
economics, which would oppose the precepts of the orthodox schools of economics (BOLIS; MORIOKA; SZNELWAR, 2014; STÅL; BONNEDAHL, 2016).

The main points considered by this economic school would be: the need for sustainable management of the resources flux through equitable distribution and efficient allocation (without exceeding the ability of natural systems to metabolise discards/wastes); the valuation of ecological aspects such as biodiversity conservation and maintenance of eco-evolutionary dynamics; the concern about carrying capacity - the maximum population size that environment can sustain - of Earth in relation to human population; the need to measure the welfare and wealth of our society more fully and comprehensively; and, lastly, the impossibility of making trade-offs between human and natural capital (BOLIS; MORIOKA; SZNELWAR, 2014).

The second step of the ladder would be "weak sustainable development", whose focus is to integrate classical conceptions of economic growth and environmental concerns. For those who encourage this approach (i.e. the "school of environmental economics"), the neoclassical principles of economics could be applied to the solution of environmental problems, maintaining economic growth as the main focus (LU, 1996). Hopwood, Mellor and O'Brien (2005) and Bolis, Morioka and Sznelwar (2014) point out that within this weak view of sustainable development, natural and manufactured capital are perceived as interchangeable, since technology would be able to fill any potential man-made harm in the natural world, such as resources scarcity. Environmental economists considers the environment as part of the economic system, since human wellbeing depends on good ecological conditions; however, environmental resources are seen in this model only as commodities and therefore can be priced (BOLIS; MORIOKA; SZNELWAR, 2014; STÅL; BONNEDAHL, 2016).

The main criticism of this conception of sustainable development lies precisely in the highly ethnocentric methods with which natural resources are approached, valuing the environment only in regard of their monetary value, while neglecting any potential cultural dimension (LU, 1996). Hence, environmental problems could be reduced to mere managerial issues: from this point of view, difficulties would be overcome in a straightforward way, without the need to promote deeper and more radical changes in political and economic systems (LU, 1996, HOPWOOD; MELLOR; O'BRIEN, 2005).

We consider that the most promising way to promote effective and lasting changes in the structure of society is through the integration of economic, social and environmental dimensions; thus, through a strong sustainable development (BANDARAGE, 2013; BOLIS; MORIOKA; SZNELWAR, 2014; STÅL; BONNEDAHL, 2016). In this integrated conception between human and natural systems, the components of economics - technology, property relations, market, finance - should be redesigned to serve the needs of environmental sustainability and human wellbeing (BANDARAGE, 2013).

The relevance of local and regional dimensions to sustainable development (LU, 1996) leads us to the next discussion in this paper: the relationship between development and entrepreneurship; furthermore, it gives us the possibility to discuss which kind of entrepreneurship would be more adequate and capable of producing positive results in a broader context. 


\subsection{Entrepreneurship}

\subsubsection{The contribution of entrepreneurship to regional development}

Entrepreneurship is the result of the interaction between individual attributes and the surrounding environment - the structural context in which the individual is inserted, what Müller and Korsgaard (2017) call the "spatial context of entrepreneurship", a phenomenon encased in individuality, but inexorably inserted in local and regional aspects. This is what, according to Audretsch (2003), makes entrepreneurship a complex and multifaceted phenomenon.

More specific and structured studies on the relationship between entrepreneurship and local/ regional development - valuing their respective contextual factors - began to appear in greater volume from the 1980s onwards (MÜLLER, 2016). For Kuratko, Morris and Schindehutte (2015), entrepreneurship represents the most important source of economic growth in several countries, as its impact can be felt in all sectors and at all levels of society. According to Szerb et al. (2015), the multidimensional interpretation of development would favour the recognition of the benefits brought by entrepreneurship, a phenomenon capable of disseminating changes in the regional context beyond creating of new jobs or increasing in GDP, for example, penetrating also social and cultural structures. This broader idea of development allows capturing the quality of entrepreneurial activity, such as the promotion of creativity and innovation, the generation of knowledge, the diffusion of technology, the creation of added value or even the diffusion of a local entrepreneurial culture that would multiply the effects of entrepreneurial activity (SZERB et al., 2015).

Morris, Neumayer and Kuratko (2015) argue, however, that analysing the benefits of entrepreneurship for regional development should not only consider technological startups as catalysts for economic growth. According to them, all types of new ventures must be considered if the long-term welfare of a region is sought. New firms, from all sectors and different growth rates, contribute to the economy levels of competition, create value for consumers, employ people, pay taxes, and ultimately contribute to the reduction of socioeconomic inequality (SZERB et al., 2015). Lyons (2015) adds that the general focus given to these technology-based startups with high growth rates may have been excessive, which could contribute to the discouragement of potential new entrepreneurs that would be interested in entering different market niches.

According to Lyons (2015), the promotion of entrepreneurship with the aim of developing a region must then be approached in a "strategic, systemic and systematic" (p. 458) way: the regional context must be considered, including the relationships and connections that are established between local stakeholders. Thus, Morris, Neumayer and Kuratko (2015) propose a typology of four kinds of firms that would serve as drivers of entrepreneurial activity and should coexist in a region if it is to develop: survival ventures, firms dedicated to the subsistence of the entrepreneur and his/her family; lifestyle ventures, companies with some formal structure, hired employees, and capable of providing the entrepreneur with a steady stream of income; managedgrowth companies, those that seek structured growth, entering new markets periodically; and high-growth ventures, high-tech companies with strong innovative capacity, seeking aggressive growth. For Morris, Neumayer and Kuratko (2015), each of these company types would have a fundamental and specific role to play in the economic landscape of a region, interacting with each other in an organic and correlational way.

This kind of systemic conception of entrepreneurship, highlighting the interconnections between stakeholders and structures of a region, allows us to understand how complex is the process that 
will ultimately culminate in local development: entrepreneurship is affected and, at the same time, affects the local context from where it develops, in a recursive dynamic (MÜLLER, 2016). This means that the regional spatial context $(R)$ conditions, to some extent, the progress of entrepreneurship $(E)$ in that locality, which will affect the regional development (RD) indicators; this will ultimately contribute to modelling the spatial context of this region (R) (MÜLLER, 2016; MÜLLER; KORSGAARD, 2017). To Müller (2016), the understanding of this recursive mechanics ( $R \rightarrow E \rightarrow R D \rightarrow R \ldots$..) would be the most complete way to understand how regional aspects and entrepreneurship combine to leverage development - but at the same time the biggest gap in researches that deal with the relations between regional aspects, entrepreneurship and development.

The comprehension that local factors are fundamental in different levels of regional entrepreneurship and that the intensity and quality of the entrepreneurial activity is capable of bringing social and economic benefits to a region, operating in a recursive mechanics (MÜLLER, 2016), is at the heart of the question we seek to address. Furthermore, the interest of Morris, Neumayer and Kuratko (2015) in a systemic view of the relationship between entrepreneurship and regional development, emphasizing the roles of the different local stakeholders that act in the creation and exploitation of an entrepreneurial environment, are the basis of our next discussion: the entrepreneurial ecosystem.

\subsubsection{Entrepreneurial Ecosystem (EE)}

The definitions of EE are diffuse, since they are constructed by researchers from different fields of knowledge (Business, Economy, Economic Geography...), each with its own methods and epistemological approaches (STAM, 2015; BROWN; MASON, 2017).

Brown and Mason (2017) posit that a territory conceived in the form of an ecosystem would give the participating stakeholders an effective way to gather resources with the purpose of generating economic wealth and prosperity at the regional level. Thus, EEs can be considered catalysts for economic progress in countries with a stable economy and a driving force for the development of economies in crisis or transition (BOUTILLIER; CARRÉ; LEVRATTO, 2016).

Alvedalen and Boschma (2017) point out that the most complete and hitherto widely accepted definition of "entrepreneurial ecosystem" is the following:

A set of interconnected entrepreneurial actors (both potential and existing), entrepreneurial organisations (e.g. firms, venture capitalists, business angels, banks), institutions (universities, public sector agencies, financial bodies) and entrepreneurial processes (e.g. the business birth rate, numbers of high growth firms, levels of 'blockbuster entrepreneurship', number of serial entrepreneurs, degree of sell-out mentality within firms and levels of entrepreneurial ambition) which formally and informally coalesce to connect, mediate and govern the performance within the local entrepreneurial environment. (MASON; BROWN, 2014, p. 5).

This definition emphasizes the systemic correlation between individuals, organizations and institutions (ALVEDALEN; BOSCHMA, 2017) and anchors such relationships in a spatial context, with geographic boundaries established to some extent (BROWN; MASON, 2017). The focus of the EE still the external business environment, but what differentiates it from other approaches that consider spatial concentration or geographic proximity as important variables for the creation of companies (e.g. clusters, industrial districts or national innovation systems) is that in the $E E$, the entrepreneur (at the individual level) plays a central role in the construction and survival of the ecosystem (STAM, 2015). In other words, in the EE the role of the individual is taken into account 
while the importance of the entrepreneurial context that surrounds him is also emphasised (STAM, 2015), considering the local infrastructure and recognising that the construction of successful entrepreneurial regions "is not simply a function of firm-specific attributes, but is mediated by the wider context within which ventures operate" (BROWN; MASON, 2017, p. 13).

According to Morris, Neumayer and Kuratko (2015), one of the cornerstones that support the systemic conception of entrepreneurship (where firms of different sizes, backgrounds and rhythms of growth coexist and correlate) as a condition for the development of a region is the existence of an entrepreneurial ecosystem. This argument is based on the idea that high-growth (HG) ventures will only develop in an environment where non-HG firms are also able to thrive.

This way, the four typologies of companies identified by Morris, Neumayer and Kuratko (2015) would compose a good sample of firms that could be found - and would enrich - an EE; Brown and Mason (2017) endorse the idea that is a "myth" (p. 15) that entrepreneurial ecosystems are formed predominantly by startups. Malecki (2018) raises the question of whether ecosystems composed mainly of high-growth companies would not conform only a sort of sub-ecosystem inside a more comprehensive EE, also populated by "ordinary firms" (p. 14).

As it was shown, the importance (and strength) of adopting the approach of entrepreneurial ecosystems involves the understanding that both the regional context and the individual capacity for action can - and should - be analysed together (STAM, 2015; ALVEDALEN; BOSCHMA, 2017; BROWN; MASON, 2017). Admitting this possibility allows us to understand the complexity of the dynamics that involve entrepreneurial activity in its varied contexts, rendering it possible to establish cause/effect relationships that sustain and shed light on the recursive interaction between regional context, entrepreneurship and development (MORRIS; NEUMAYER; KURATKO, 2015; MÜLLER, 2016).

Moreover, the desirable variety of business types present in an entrepreneurial ecosystem (MORRIS; NEUMAYER; KURATKO, 2015; BROWN; MASON, 2017; MALECKI, 2018) opens the possibility for us to talk about entrepreneurs who act sustainably, even beyond the traditional market limits, prioritising companies with environmental and social ends, and considering profit only as a means to achieve such objectives (PARRISH, 2008).

\subsubsection{Sustainable Entrepreneurship}

Sustainable entrepreneurship highlights the importance of entrepreneurial solutions to social and environmental problems (MUÑOZ; COHEN, 2018). The fundamental idea behind sustainable entrepreneurship is that the activities developed by entrepreneurs in pursuit of opportunities should not debilitate the ecological and social environments in which they operate (SHEPHERD; PATZELT, 2011). Sustainable entrepreneurs should seek to restore the balance between nature, society and economic activity, in conformity with the integration between human and natural systems, as discussed by Bandarage (2013).

For Muñoz and Cohen (2018), sustainable entrepreneurship has the potential to create radical changes in the relationships between socioeconomic and natural dimensions. By using their companies as vehicles to the improvement of environmental quality and social welfare levels, besides meeting their own personal goals, sustainable entrepreneurs can generate impacts on a broader scale, promoting societal changes towards a more equalitarian and sustainable future (PARRISH; FOXON, 2006). 
Stål and Bonnedahl (2016) show that, due to the incipient nature of this sub-area, publications on sustainable entrepreneurship are not necessarily cohesive and mostly follow the mainstream positions of sustainable development: basically dealing with traditional business models that seek to incorporate a weak sustainable discourse based on the monetization and pricing of natural resources (STÅL; BONNEDAHL, 2016).

Within this perspective, sustainable entrepreneurship would address social and environmental problems using solutions that operate within the market failures inherent to the economic system and which would, thus, serve as opportunities for new business. Therefore, environmental and social problems would be considered only a consequence of the entrepreneurial activity, which would be, initially, concentrated in the economic sphere as being both the means and end of a business (PARRISH, 2008). This understanding of entrepreneurial opportunity would, according to Stål and Bonnedahl (2016), make entrepreneurs overly dependent on market mechanisms. According to the authors, this weak perspective of sustainable development (and sustainable entrepreneurship) has been "slow or even inappropriate to address the pressing [environmental] issues [...] and satisfaction of basic human needs" (STÅL; BONNEDAHL, 2016, p. 1).

According to Stål and Bonnedahl (2016), the type of sustainable entrepreneurship that could best contribute to overcoming socioeconomic and environmental issues would be based on a strong sustainable development. Thus, strong sustainable entrepreneurship (SSE) would depend on entrepreneurs' ability to envisage new ways of defining value that, at least in part, would be separated from "market demands" (STÅL; BONNEDAHL, 2016); in such cases, value creation could be achieved, for example, using sustainable business models that operate beyond conventional markets (PARRISH, 2008). SSE would then emerge as a "creative problem-solver" (STÅL; BONNEDAHL, 2016, p. 10), making it possible to conserve and improve the conditions of the available critical natural capital, and thus be effectively aligned with the objectives of development beyond the economic interest of serving the demands of the market.

Finally, sustainable entrepreneurship has the potential to recognise and analyse the systemic interactions between socioeconomic and environmental spheres. It also highlights the importance of regional contexts (in their social, economic and natural dimensions) as facilitators/inhibitors of sustainable entrepreneurship activity. Moreover, the concept of sustainable entrepreneurship allows to establish a broader perspective of the idea of value creation, capable of recognising ecological, social and economic systems where sustainable entrepreneurs are embedded and operate within (MUÑOZ; COHEN, 2018).

\section{PROPOSED THEORETICAL FRAMEWORK}

\subsection{Dependent variable: (Sustainable) Regional Development}

We start from the basic premise that the mainstream (classical/neoclassical) development model focuses merely on economic metrics and does not contemplate other primordial dimensions to achieve wellbeing, namely: environmental and social (LU, 1996; HOPWOOD; MELLOR; O'BRIEN, 2005; BANDARAGE, 2013). In another words, we consider that the development model best aligned with the global context of the 21st century, when ecological degradation and social inequalities are mounting, should present a sustainable aspect. Thus:

- P1: Regional development, in the 21st century, needs to be sustainable.

Additionally, we consider that the attribute that exerts the greatest transforming power

INTERAÇÕES, Campo Grande, MS, v. 21, n. 4, p. 739-752, out./dez. 2020 
on the socioeconomic and environmental scenario is the strong sustainable development (HOPWOOD; MELLOR; O'BRIEN, 2005; BANDARAGE, 2013; STÅL; BONNEDAHL, 2016). Based on this position, we posit that:

- P1a: Strong sustainability contemplates in a more balanced/equalitarian way the economic, social and environmental dimensions.

\subsection{Independent variables: Entrepreneurship and Sustainability}

Entrepreneurship - Based on the literature review presented, it was possible to verify that the entrepreneur's role in regional development has been considered one of great relevance and has been receiving systematic attention since the 1980s (MÜLLER, 2016). In this way:

- P2: Entrepreneurship is an important lever for regional development.

Accepting this premise, we can say that the conformation of entrepreneurial ecosystems can be of fundamental value in mobilising local stakeholders and fostering entrepreneurial activity with enough robustness to have an impact at the local/regional level (SZERB et al., 2015; MORRIS; NEUMAYER; KURATKO, 2015). We should also mention that this virtue of the entrepreneurial ecosystem is based on the recognition that companies of all types benefit from this kind of arrangement and can, therefore, contribute systematically to the development of a region (MORRIS; NEUMAYER; KURATKO, 2015; BROWN; MASON, 2017; MALECKI, 2018). Consequently:

- P2a: Entrepreneurial Ecosystem would have a prominent and strategic role in fulfilling the potential of entrepreneurship as a lever for regional development.

Sustainability - With attention to social and environmental indexes, including qualitative ones, sustainable development will be achieved. Within this scope, and considering the strength of entrepreneurship to foster development, we believe that the most appropriate kind of entrepreneurship would be sustainable entrepreneurship (PARRISH; FOXON, 2006; MUÑOZ; COHEN, 2018). Thus:

- P3: To better comply with the precepts of sustainable development, the most appropriate type of entrepreneurship is, therefore, sustainable entrepreneurship.

The validity of P3 being accepted, we highlight the importance of the precepts of strong sustainability in the strategic planning of new ventures (PARRISH, 2008; STÅL; BONNEDAHL, 2016); this could be especially interesting to promote a deeper structural change in the social and environmental dimensions of a region. Therefore, we propose that:

- P3a: Strong sustainable entrepreneurship holds the greatest ability to contemplate in a balanced/egalitarian manner the economic, social and environmental dimensions.

Recursive mechanics - For Müller (2016) the relationships between entrepreneurship (including sustainable entrepreneurship) and regional development (incorporating sustainability precepts) is only complete when contemplated in a recursive mechanics: $R \rightarrow E \rightarrow R D \rightarrow R$..., where $R$ represents the regional context; $E$ represents the levels of entrepreneurship; and $R D$ represents regional development. That is, the spatial context affects the levels of entrepreneurship in a region; consequently, it will affect the levels of regional development. In a recursive mechanics, the levels of regional development will contribute to shaping the socioeconomic and natural context of a region, which will affect entrepreneurship and so on. Therefore:

- P4: The relationship between the socioeconomic and natural aspects of a region, its levels of entrepreneurship and regional development occurs under a recursive mechanics. 
Thus, the theoretical model presented (Figure 1) displays the proposed relations:

Figure 1-Theoretical framework of the research

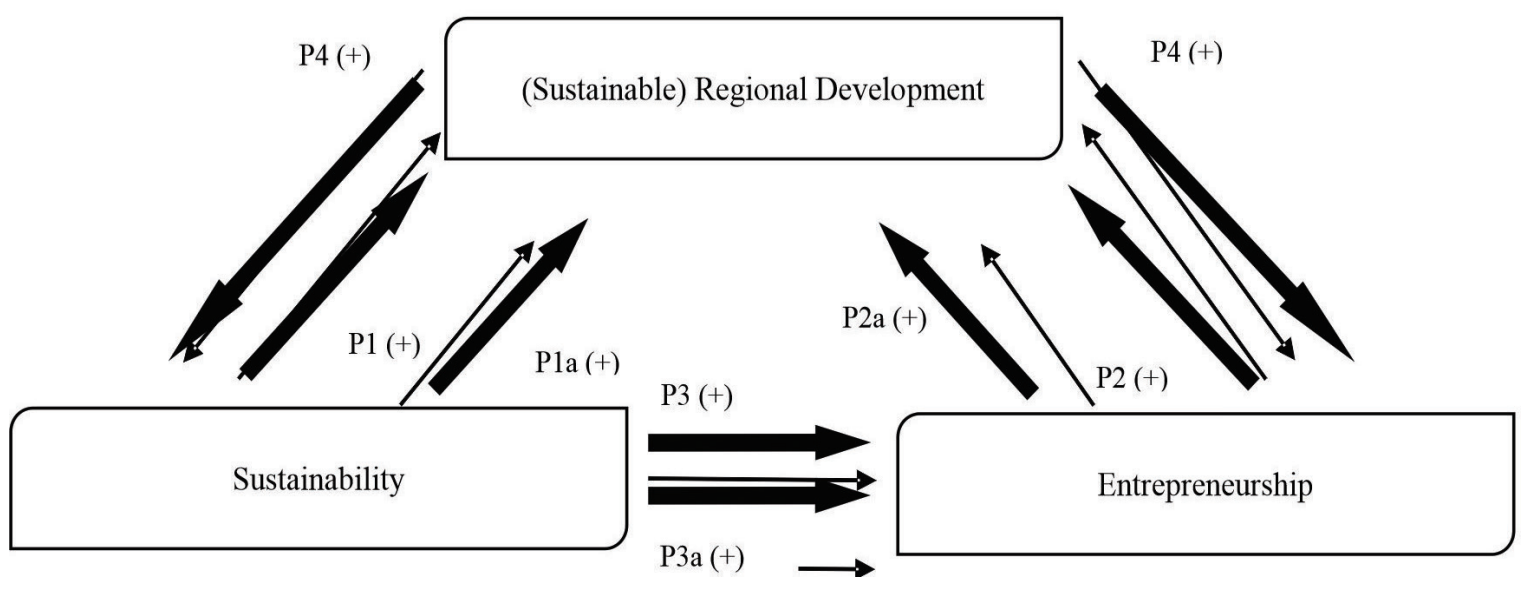

Source: elaborated by the authors.

\section{DISCUSSION}

The demand for greater attention to environmental issues in economic debates gained momentum particularly since the end of the twentieth century (LU, 1996). There is also a growing understanding that the regions are determinant and strategic for the development of the global economy regarding the preservation of local natural ecosystems and traditional communities: Hopwood, Mellor and O'Brien (2005) consider that small and local is more sustainable than large and global; for Bandarage (2013), sustainable development would allow the insertion of the local and regional levels in the route of global economy via entrepreneurship. Hence, the goal is a sustainable and socially responsible globalization that allows a fairer relationship between global and local levels of economic activity. Stål and Bonnedahl (2016) consider that a strong sustainable entrepreneurship has a fundamental role to play in both socioeconomic and environmental fronts, integrating those perspectives. The attention to natural resources may even be a differential for the entrepreneurs' business, serving as a potential competitive advantage (MUÑOZ; COHEN, 2018).

Entrepreneurial activity is particularly important in this context, since it has been a driving force for regional economic and social development (AUDRETSCH, 2003; KURATKO; MORRIS; SCHINDEHUTTE, 2015), both in developed regions and in the so-called "peripheries" (BOUTILLIER; CARRÉ; LEVRATTO, 2016), because of their capacity to create jobs and disseminate a certain "local entrepreneurial culture" (SZERB et al., 2015). The strength of entrepreneurship in articulating regional and global levels, promoting a regional development that contemplates the improvement of the living conditions of a population in a given territory, comes precisely from the entrepreneur's ability to uniquely combine resources available in a region and to generate profitable activities that ultimately have their dividends (re)invested locally (MÜLLER, 2016). By mobilising the local stakeholders in joint efforts to establish a positive environment for the entrepreneurial activity in a region, the creation of entrepreneurial ecosystems can serve as catalyst for development (BROWN; MASON, 2017).

It was precisely this relationship between development, entrepreneurship and sustainability that we proposed to articulate in the theoretical framework presented. The model aims to 
explain how sustainable development can be achieved, improving the quality of life at large, by linking the (strong) sustainability precepts to the increase of entrepreneurial activity in a region. Entrepreneurship would enable greater involvement of the local population in the global economy; moreover, in being sustainable, it would bring greater attention to the need for environmental preservation, allowing the establishment of new eco-based businesses models and serving as an instrument of environmental education for the population. Additionally, the inherent recursive mechanics between regional context, entrepreneurship and development would guarantee the evolution of the territorial dynamics of a given region (MÜLLER, 2016; MÜLLER; KORSGAARD, 2017).

\section{CONCLUSIONS}

The objective of this paper was to propose a theoretical framework in which sustainable regional development is the dependent variable, mediated by entrepreneurship and sustainability as independent variables. Our main goal was to show how entrepreneurship is increasingly responsible for improving general living conditions in a region (SZERB et al., 2015; MORRIS, 2015; MÜLLER, 2016); a proof of this is the dissemination of the entrepreneurial concept amongst practitioners and policy makers - a dynamic and ever-evolving productive arrangement, constantly open to new entrants (MALECKI, 2018), involving diverse local stakeholders (MASON; BROWN, 2014) - in order to promote the creation of new companies, regardless of their profile (MORRIS; NEUMAYER; KURATKO, 2015).

However, in order to promote a strong sustainable development (HOPWOOD; MELLOR; O'BRIEN, 2005), a greater emphasis must be put on sustainable entrepreneurship, a niche with great potential to be explored (MUÑOZ; COHEN, 2018). The strong sustainable entrepreneurship approach holds the greatest capacity to bring deeper and lasting changes to the socioeconomic and natural structure of a region (STÅL; BONNEDAHL, 2016).

Considering the literature review and theoretical framework proposed, this research can contribute to: (i) the progress of studies on sustainable regional development; the research on sustainable entrepreneurship, a still incipient branch of entrepreneurship studies; and, finally, the studies on entrepreneurial ecosystem, another concept that lacks theoretical maturation; and (ii) serve as a theoretical basis for researchers seeking to conduce empirical studies involving the relationship between development, sustainability and entrepreneurship, as it links aspects that have not yet been thoroughly investigated theoretically nor empirically.

The lack of indicators/indexes and a suitable methodology to measure the correlation of the constructs involved in this model is still a limitation. This clarification would enhance the empirical validity of the model, since it would establish in an objective way what data would be related to each one of the indicators, aiding their collection and analysis.

Thus, we believe that the model presented here may be useful for future research on the links between sustainable development and entrepreneurship. In this sense, this framework can be useful for public managers, research institutions, investors and entrepreneurs who envisage the potential to act locally in a sustainable way; that is, any stakeholder who might be involved in an entrepreneurial ecosystem. 


\section{REFERENCES}

ALVEDALEN, Janna; BOSCHMA, Ron. A critical review of entrepreneurial ecosystems research: towards a future research agenda. European Planning Studies, London, v. 25, n. 6, p. 887-903, 2017.

AUDRETSCH, David. Entrepreneurship: a survey of the literature. Enterprise Papers, Brussels, v. 14, p. $1-73,2003$.

BANDARAGE, Asoka. Sustainability and well-being: the middle path to environment, society and the economy. Basingstoke: Palgrave Macmillan, 2013.

BOLIS, Ivan; MORIOKA, Sandra; SZNELWAR, Laerte. When sustainable development risks losing its meaning. Delimiting the concept with a comprehensive literature review and a conceptual model. Journal of Cleaner Production, Amsterdam, v. 83, p. 1-32, 2014.

BOUTILLIER, Sophie; CARRÉ, Denis; LEVRATTO, Nadine. Entrepreneurial Ecosystems. London: John Wiley \& Sons, 2016.

BROWN, Ross; MASON, Colin. Looking inside the spiky bits: a critical review and conceptualisation of entrepreneurial ecosystems. Small Business Economics, Berlin, v. 4, n. 1, p. 11-30, 2017.

BRUNDTLAND, Gro Harlem. Environment and development challenges: the imperative to act. Nairobi: UN/Unep, 2012.

HOPWOOD, Bill; MELLOR, Mary; O’BRIEN, Geoff. Sustainable development: mapping different approaches. Sustainable Development, Hoboken, v. 13, p. 38-52, 2005.

KURATKO, Donald; MORRIS, Michael; SCHINDEHUTTE, Minet. Understanding the dynamics of entrepreneurship through framework approaches. Small Business Economics, Berlin, v. 45, n. 1, p. 1-13, 2015.

LU, Aiguo. Environment and Development. In: TENG, T.; YIFAN, D. (Org.). Environment and Development. Paris: Unesco, 1996.

LYONS, Thomas. Entrepreneurship and community development: what matters and why? Community Development, Abingdon-on-Thames, v. 46, n. 5, p. 456-60, 2015.

MALECKI, Edward. Entrepreneurship and entrepreneurial ecosystems. Geography Compass, Hoboken, v. 12, n. 1, p. 1-21, 2018.

MASON, Colin; BROWN, Ross. Entrepreneurial Ecosystems and Growth Oriented Entrepreneurship. Workshop of the OECD LEED Programme and the Dutch Ministry of Economic Affairs. Den Haag, The Netherlands, 2014.

MORRIS, Michael; NEUMEYER, Xaver; KURATKO, Donald. A portfolio perspective on entrepreneurship and economic development. Small Business Economics, Berlin v. 45, p. 713-28, 2015.

MÜLLER, Sabine. A progress review of entrepreneurship and regional development: what are the remaining gaps? European Planning Studies, London, v. 24, n. 6, p. 1133-58, 2016.

MÜLLER, Sabine; KORSGAARD, Steffen. Resources and bridging: the role of spatial context in rural entrepreneurship. Entrepreneurship \& Regional Development, Abingdon-on-Thames, v. 30, n. 1-2, p. $1-32,2017$. 
MUÑOZ, Pablo; COHEN, Boyd. Sustainable entrepreneurship research: taking stock and looking ahead. Business Strategy and the Environment, Hoboken, v. 27, v. 3, p. 300-22, 2018.

PARRISH, Bradley. Sustainability-Driven entrepreneurship: a literature review. Sustainability Research Institute Papers, Leeds, v. 9, p. 1-57, 2008.

PARRISH, Bradley; FOXON, Timothy. Sustainability entrepreneurship and equitable transitions to a lowcarbon economy. Greener Management International, New York, v. 55, p. 47-62, 2006.

SHEPHERD, Dean; PATZELT, Holger. The new field of sustainable entrepreneurship: studying entrepreneurial action linking 'what is to be sustained' with 'what is to be developed'. Entrepreneurship: Theory and Practice, Thousand Oaks, v. 35, n. 1, p. 137-63, 2011.

STÅL, Herman; BONNEDAHL, Karl. Conceptualizing strong sustainable entrepreneurship. Small Enterprise Research, Abingdon-on-Thames, v. 23, n. 1, p. 1-12, 2016.

STAM, Erik. Entrepreneurial ecosystems and regional policy: a sympathetic critique. European Planning Studies, London, v. 23, n. 9, p. 1759-69, 2015.

SZERB, László; ÁCS, Zoltán; KOMLÓSI, Éva; ORTEGA-ARGILÉS, Raquel. Measuring entrepreneurial ecosystems: the Regional Entrepreneurship and Development Index (REDI). Henley Centre for Entrepreneurship, Henley Business School. Reading, UK: University of Reading, 2015.

\section{About the authors:}

Paulo Vitor Siffert: Doctoral student at the Postgraduate Program in Business - Pontifical Catholic University of Minas Gerais (PUC Minas). E-mail: siffert13@icloud.com, Orcid: http://orcid.org/0000-0003-2010-7991

Liliane de Oliveira Guimarães: Doctorate in Business at the Getulio Vargas Foundation - São Paulo (FGV-SP). Professor at the Postgraduate Program in Business - Pontifical Catholic University of Minas Gerais (PUC Minas). E-mail: lilianeog@pucminas.br, Orcid: http://orcid.org/0000-0002-3346-2207 